No 4078

Studia nad Autorytaryzmem i Totalitaryzmem 43, nr 4 Wrocław 2021

https://doi.org/10.19195/2300-7249.43.4.14

\author{
MAGDALENA WASYLKOWSKA-MICHÓR \\ ORCID: 0000-0002-5810-9186 \\ Uniwersytet Zielonogórski \\ m.wasylkowska-michor@wpa.uz.zgora.pl
}

\title{
Prawo właściwe dla zobowiązań niewynikających z czynności prawnych w okresie Polskiej Rzeczypospolitej Ludowej
}

Slowa kluczowe: zobowiązanie pozaumowne, lex loci delicti commissi, prawo miejsca zamieszkania, Polska Rzeczpospolita Ludowa, zobowiązanie niewynikające z czynności prawnej.

\author{
LAW APPLICABLE TO OBLIGATIONS NOT ARISING OUT \\ OF LEGAL ACTION IN THE POLISH PEOPLE'S REPUBLIC
}

\begin{abstract}
In the communist era, the law applicable to non-contractual obligations was regulated by two acts - the Private International Law of 1926 and the Private International Law of 1965, which dealt with the issue of the law applicable to obligations not arising out of legal action. The object of this study is to present the respective regulations in terms of determining this law. In particular, the author focuses on the analysis of two main connecting factors used at that time to determine the law applicable to non-contractual obligations, namely, the law of the place where the act giving rise to the non-contractual obligation was performed and the law of domicile. In the conclusion of the article the author assesses the solutions presented above from the point of view of both Polish and foreign doctrine.
\end{abstract}

Keywords: non-contractual obligation, lex loci delicti commissi, law of domicile, Polish People's Republic, obligation not arising from legal action. 


\section{Wstęp}

Celem niniejszego artykułu jest przedstawienie regulacji prawa właściwego dla zobowiązań niewynikających z czynności prawnych w dobie PRL. W pierwszej kolejności zatem należy ustalić, jaki okres możemy tu zaliczyć, a następnie które ustawy dotyczące materii będącej przedmiotem niniejszego artykułu obowiązywały w tym czasie. Za okres historycznie zwany PRL lub bardziej potocznie Polską Ludową uważa się lata 1952-1989. Dnia 31 grudnia 1989 roku weszła w życie nowelizacja, która wprowadzała do konstytucji nową nazwę państwa, przywracała przedwojenne godło i wykreślała ideologiczne deklaracje zawarte w ustawie zasadniczej z roku 1952. Tego dnia określenie Polska Rzeczpospolita Ludowa przeszło do historii. W tym okresie prawo właściwe dla zobowiązań pozaumownych regulowały dwie ustawy - prawo prywatne międzynarodowe z 1926 roku $^{1}$ oraz prawo prywatne międzynarodowe z 1965 roku $^{2}$. Główną zasadą regulującą prawo właściwe dla czynów niedozwolonych na gruncie tych dwóch ustaw było lex loci delicti commissi - prawo właściwe dla miejsca wystąpienia zdarzenia będącego przyczyną czynu niedozwolonego.

\section{Właściwość prawa miejsca popełnienia czynu w prawie polskim}

Artykuł 11 ustawy prawo prywatne międzynarodowe z 1926 roku stanowił, że zobowiązania $\mathrm{z}$ występków i innych zdarzeń prawnych podlegają prawu państwa, gdzie zaszedł fakt, który wywołał zobowiązanie. To samo prawo rozstrzyga, czy osoba w swej zdolności osobistej ograniczona odpowiada za wyrządzoną szkodę. W tym miejscu należy zwrócić uwagę na fakt, że poprzez posłużenie się określeniem ,zobowiązania z występków i z innych zdarzeń prawnych” zakres normy został od razu zakreślony bardzo szeroko. Autorzy projektu utrzymywali bowiem, że chodzi tutaj nie tylko o zobowiązania pozaumowne, ale także i te, które wynikają z jednostronnych czynności prawnych. Podobnie szeroko rozumiany był $\mathrm{w}$ orzecznictwie łącznik wyrażający się w określeniu „fakt, który wywoła zobowiązanie". W przypadku, gdyby działanie rozgrywało się w kilku miejscach, decydujące miało być to zakończenia czynu. Z kolei w przypadku zamieszkania za właściwe uważano miejsce, gdzie zaniechana czynność powinna być dokonana ${ }^{3}$.

${ }^{1}$ Ustawa z dnia 2 sierpnia 1926 roku o prawie właściwym dla stosunków prywatnych międzynarodowych (Dz.U. Nr 101, poz. 581 ze zm.).

2 Ustawa z dnia 12 listopada 1965 roku - Prawo prywatne międzynarodowe (Dz.U. z 1965 r. $\mathrm{Nr}$ 46, poz. 290).

3 M. Sośniak, Lex loci delicti comissi w prawie międzynarodowym prywatnym, ,Studia Cywilistyczne" 1963, nr 4, s. 13. 
Jeśli chodzi o ustawę prawo prywatne międzynarodowe z 1965 roku, to właściwość prawa miejsca deliktu przewidywała w art. $31 \S 1$, jeśli nie zachodzily warunki do zastosowania $\S 2$, to znaczy — o ile obydwie strony nie były obywatelami tego samego państwa i nie miały w nim jednocześnie miejsca zamieszkania. $Z$ powyższego wynikało zatem, że ustawa nie precyzowała, czy chodzi o miejsce wystąpienia faktu, który spowodował odpowiedzialność, czy też szkody. Co więcej, pojęcie „miejsce deliktu” nie zostało nigdy zdefiniowane w żadnej regulacji prawnej.

Sformułowanie $\S 1$ zostało pozytywnie ocenione przez Mieczysława Sośniaka. Utrzymywał on bowiem, że dzięki takiej konstrukcji ustawodawca nie przesądził ostatecznie o przyjęciu jako właściwego prawa miejsca popełnienia czynu też prawa miejsca wystąpienia skutku. Wprost przeciwnie $-\S 1$ umożliwiał szeroką interpretację $\mathrm{w}$ zależności od konfiguracji poszczególnych elementów stanu faktycznego. Tak więc w przypadku odpowiedzialności opartej na zasadzie winy lokalizacja powinna nastąpić w miejscu czynu, a więc tam, gdzie działała osoba odpowiedzialna. Z kolei w przypadku lekkiej nieostrożności czy też niedbalstwa, które ujmuje się jako odpowiedzialność zobiektywizowaną, decydujące powinno być miejsce, w którym należało urzeczywistnić model należytego zachowania, decydujący o możliwości postawienia zarzutu osobie odpowiedzialnej. Następnie autor dokonuje dalszego zróżnicowania rodzajów odpowiedzialności. I tak w przypadku odpowiedzialności za cudze czyny czy też zwierzęta (art. 430 kc), pomimo oparcia tej odpowiedzialności na zasadzie winy, powinno się brać pod uwagę nie miejsce, w którym działała osoba odpowiedzialna, ale to, gdzie działała osoba, nad zwierzęciem której miano roztoczyć nadzór, bądź to, gdzie nastąpił szkodliwy skutek braku nadzoru. Podobnie w przypadku tak zwanej odpowiedzialności opartej na zasadzie ryzyka należało brać pod uwagę miejsce, w którym doszło do wystąpienia szkody. W przypadku szkody doznanej na skutek zaniechania sprawcy należało brać pod uwagę miejsce, gdzie istniał obowiązek zaniechanego działania. Zasady te należało przy tym traktować tylko jako pewne wskazówki po to, aby uniknąć nadmiernego schematyzmu. Reasumując, M. Sośniak uzależniał zastosowanie prawa danego państwa od stopnia powiązania czynu z określonym terytorium. Natężenie tego związku, z jednej strony, oraz elementy, jakie w danym delikcie wysuwają się na pierwszy plan, z drugiej, decydują o tym, który z kilku ewentualnie wchodzących w grę czynników ma zostać uznany za decydujący dla wyboru właściwości prawa. Sąd był obowiązany do badania w każdym przypadku siły tego powiązania i dostosowania rozstrzygnięcia kolizyjnego do specyfiki stanu faktycznego deliktu ${ }^{4}$.

Pozytywnym aspektem rozwiązania przyjętego przez M. Sośniaka jest to, że poszukiwał on sposobu uelastycznienia sztywnego łącznika lex loci delicti commissi, jednakże nie można się już zgodzić z wprowadzaniem przez tego

${ }^{4}$ M. Sośniak, Zobowiązania nie wynikające z czynności prawnych w prawie prywatnym międzynarodowym, Katowice 1971, s. 91-96. 
autora rozwiązań znanych w kolizjonistyce amerykańskiej, a to różnicowania zasady wskazania prawa właściwego od tego, który z elementów odnośnego stanu faktycznego jest najbardziej dominujący. Należy mieć bowiem na uwadze fakt, że w przypadku Stanów Zjednoczonych do takich działań upoważniało literalne brzmienie przepisów, chociażby Restatement II. Z kolei nie budziło żadnych wątpliwości stanowisko, że nie należy łącznika z art. $31 \S 1$ rozumieć szeroko w kontekście społecznego otoczenia deliktu, ponieważ ustawa polska posługuje się pojęciem ,państwa, w którym nastąpiło zdarzenie będące źródłem zobowiązania”, co nie oznaczało oczywiście, że nie należy uwzględniać innych niż geograficzne czynników ${ }^{5}$.

Wobec zmian wprowadzonych ustawą z dnia 4 lutego 2011 roku prawo prywatne międzynarodowe zasada lex loci delicti commissi ma obecnie $\mathrm{w}$ prawie polskim znaczenie tylko historyczne. Oznacza to całkowita rewolucję w polskiej kolizjonistyce $\mathrm{w}$ zakresie prawa właściwego dla czynów niedozwolonych, jako że, jak zostało to już wyżej nadmienione, była to zasada główna zarówno w ustawie z 1926, jak i z 1965 roku.

\section{2. Łącznik miejsca zamieszkania w prawie polskim}

Artykuł $31 \S 2$ stanowiący, że gdy strony są obywatelami tego samego państwa i mają w nim miejsce zamieszkania, właściwe jest prawo tego państwa, należał natomiast do grupy II, gdzie obydwie podstawy miały pozycję równorzędną ${ }^{6}$. Na gruncie tego przepisu kontrowersyjne było to, czy można go stosować także do bezpaństwowców. Większość doktryny opowiedziała się za takim rozwiązaniem ${ }^{7}$.

Łącznik miejsca zamieszkania występował w ustawie prawo prywatne międzynarodowe z 1965 roku bądź jako łącznik samoistny (art. 26, 27 § 1 i 33 § 1),

5 T. Pajor, Odpowiedzialność deliktowa w prawie prywatnym międzynarodowym, Warszawa 1989, s. 177-181. Pierwszeństwo zasady lex loci delicti commissi było w doktrynie przedmiotu bardzo różnie uzasadniane. Tłumaczono konieczność zastosowania tej zasady między innymi uzasadnieniem społecznym (A Pillet, Traité pratique de droit international privé, t. 2, Paryż 1923, s. 312, cyt. za: M. Sośniak, Zobowiazania ..., s. 29), terytorialnym charakterem ustaw dotyczących odpowiedzialności deliktowej (J.P Niboyet, Traité de droit international privé français, t. 5, Paryż 1948, s. 148, cyt. za: M. Sośniak, Zobowiązania..., s. 29), obowiązkiem zapewnienia przez każde państwo przynajmniej minimalnej ochrony wszystkim osobom przebywającym na jego terytorium bez względu na przynależność państwową (obywatelstwo), naturą zobowiązania deliktowego, (P. Arminjon, Précis de droit international privé, t. 2, Paryż 1934, s. 348, cyt. za: M. Sośniak, Zobowiązania..., s. 29).

6 Trzecią grupę stanowią przepisy, w których łącznik zamieszkania zajmuje pozycję samodzielną. Sytuacja taka wchodzi w grę w przypadku zobowiązań niedotyczących nieruchomości i niezawartych na giełdzie ani targach publicznych, jeżeli strony nie dokonały wyboru prawa (zob. A. Mączyński, Zamieszkanie jako podstawa łącznika normy kolizyjnej, „Zeszyty Naukowe UJ” 1978, nr 81, s. 45-50).

7 A. Mączyński, op. cit., s. 45-50. 
bądź posiłkowy (zamiast obywatelstwa, w razie jego braku — art. 3) lub też łącznie z łącznikiem obywatelstwa.

Na tle przyjętego rozwiązania doszło do rozbieżności interpretacyjnych. W opinii przedstawicieli części doktryny przepis $§ 2$ należało traktować jako wyjątek od reguły wyrażonej $\S 1^{8}$, natomiast zwolennicy inni ${ }^{9}$ twierdzili, że pierwszeństwo zastosowania ma zawsze $\S 2$, ponieważ nim sąd zastosuje $\S 1$, musi najpierw zbadać, czy strony nie mają wspólnego obywatelstwa i jednocześnie wspólnego miejsca zamieszkania. Tym niemniej jednak przepis $\S 1$ nie mógł być traktowany jako swego rodzaju norma posiłkowa w sytuacji, gdy występowały trudności ze stosowaniem $\S 2$. W końcu przeważył pogląd, że normy zawarte w $\S 1$ i 2 należało traktować jako dwie zupełnie odmienne normy kolizyjne, czego konsekwencją było to, że w sytuacji, gdy nie było podstaw do zastosowania $\S 2$, automatycznie nie stosowano $\S 1$, a następowało sięgnięcie do art. 7 . W przeciwnym bowiem razie $\S 1$ byłby stosowany tylko posiłkowo w stosunku do $\S 2$. Takie stanowisko prezentowała też Barbara Tracz-Pasternak. W jej ocenie $\S 1$ i 2 to dwie zupełnie różne normy, między którymi nie ma związku. Co więcej, w przypadku, gdy $\mathrm{z}$ ustaleń stanu faktycznego wynika, że zastosowania nie znajdzie $\S 2$, wówczas należy odwoływać się do regulacji art. 7 , a nie $\S 1^{10}$.

Warto w tym miejscu zwrócić uwagę na fakt, że w doktrynie przedmiotu przeciwko konstrukcji $§ 2$ art. 31 wysuwane były liczne zastrzeżenia. Chodziło mianowicie o to, że zastosowany w nim łącznik personalny opierał się aż na dwóch podstawach: obywatelstwie i miejscu zamieszkania, co bardzo komplikowało jego zastosowanie w praktyce i było wyrazem pewnej asekuracji ustawodawcy czyniącego ustępstwo od zasady legis loci delicti. Przepis $\S 2$ art. 31

${ }^{8}$ Do zwolenników pierwszej grupy należą W. Ludwiczak, E. Wierzbowski. K. Przybyłowski zajmuje stanowisko nie do końca sprecyzowane. Za traktowaniem $\S 2$ jako wyjątku przemawia niewątpliwie zastosowanie określenia ,jednakże gdy" oraz umieszczenie tego rozwiązania kolizyjnego właśnie w $\S 2$, a nie w $\S 1$, co wskazuje na fakt, że to $\S 1$ stanowi zasadę. Ponadto należy pamiętać o wykładni historycznej, w wyniku której pierwszeństwo ma zasada lex loci delicti commissi. Przeciwko takiemu stanowisku wysuwane są jednakże liczne argumenty. Do najważniejszych należy ten, który wskazuje na konieczność stosowania w takim wypadku ścisłej interpretacji, co uniemożliwiłoby poniekąd dalsze uelastycznianie i różnicowanie reguł kolizyjnych (zob. T. Pajor, op. cit., s. 143-145).

${ }^{9}$ Zwolennicy drugiego poglądu to przede wszystkim M. Sośniak i H. Trammer. Twierdzą oni, że za przyjęciem $\S 2$ jako zasady przemawia kolejność operacji myślowych sędziego, który najpierw musi zadać sobie pytanie, czy strony mają wspólne miejsce zamieszkania i obywatelstwo, a dopiero w następnej kolejności zwraca się ku właściwości miejscowej. Przeciwko temu stanowisku przemawia fakt, że nie można dla ustalenia, czy mamy do czynienia z zasadą prawa, powoływać się na tok myślenia sędziego. Ponadto przedstawiony przez wymienionych autorów proces myślowy wprost przeciwnie przemawia za tym, że rozwiązanie $§ 2$ należy stosować jako wyjątek. Sędzia bowiem najpierw eliminuje przepis stanowiący wyjątek, by móc powołać się na zasadę (zob. T. Pajor, op. cit., s. 143-145).

10 B. Tracz-Pasternak, Wtaściwość prawa personalnego stron dla zobowiazań niewynikajacych z czynności prawnych, „Państwo i Prawo” 1980, nr 2, s. 87-88. 
nie precyzował również, czy dotyczy tylko i wyłącznie bezpośredniego sprawcy szkody i bezpośrednio poszkodowanego, czy znajdował także zastosowanie w przypadku osób bezpośrednio poszkodowanych i pośrednio odpowiedzialnych za szkodę. W doktrynie przeważał pogląd, że wobec brzmienia przepisu dopuszczalne było stanowisko drugie. Przepis ten jednak nie dotyczył osób, które tylko wstąpiły w prawa lub obowiązki stron stosunku deliktowego ${ }^{11}$.

Następne trudności interpretacyjne rodziła sytuacja, w której po jednej lub każdej ze stron występował więcej niż jeden podmiot. Mogło się bowiem wtedy zdarzyć, że byłoby na przykład dwóch sprawców szkody, z których tylko jeden miałby takie samo obywatelstwo i miejsce zamieszkania jak poszkodowany. Powstałaby wtedy sytuacja, kiedy w jednym stanie faktycznym zastosowanie miałyby dwie normy — ta z art. $31 \S 1$ i z $\S 2$, przy czym mogło się okazać, że w ten sposób wskazane zostaną prawa innych państw, które mogą w odmienny sposób regulować sytuację osób poszkodowanych ${ }^{12}$.

Ponadto przepis nie podawał, jaka chwila była miarodajna dla określenia wspólności obywatelstwa i zamieszkania, a mianowicie, czy chodziło tu o chwilę, w której doszło do zdarzenia wyrządzającego szkodę, nastąpienia samej szkody, czy też może wystąpienia $\mathrm{z}$ roszczeniem odszkodowawczym lub wyrokowania. $\mathrm{W}$ doktrynie przyjmowało się, że chodzi o moment zajścia samego zdarzenia, a wszelka następcza zmiana sytuacji stron nie miała w tym wypadku większego znaczenia $^{13}$. Za taką interpretacją zdawał się również przemawiać fakt, że w $\S 1$ art. 31 ustawodawca posłużył się łącznikiem prawa miejsca deliktu, co niejako pośrednio wskazywało na chwilę wystapienia zdarzenia powodującego szkode jako najbardziej miarodajną dla ustalenia wspólności prawa stron. Nie należy bowiem zapominać, że pomimo wyrażanych niekiedy w doktrynie przeciwnych stanowisk obydwa paragrafy art. 31 pozostawały ze sobą w funkcjonalnym związku. Problem

11 T. Pajor, op. cit., s. 169-175.

$12 \mathrm{~W}$ literaturze proponuje się kilka rozwiązań. W pierwszej kolejności nasuwa się pytanie, czy po to, aby wyeliminować rozwiązanie niekorzystne dla stron, można sięgnąć po klauzulę porządku publicznego $\mathrm{z}$ art. 6 , zgodnie $\mathrm{z}$ którą prawa obcego stosować nie można, jeżeli jego stosowanie miałoby skutki sprzeczne z podstawowymi zasadami porządku prawnego Rzeczypospolitej Polskiej. Z brzmienia tego przepisu wynika jednak wprost, że nie chodzi tu o sytuację, kiedy norma prawa obcego jest sprzeczna $z$ normą prawa polskiego, ale o taką, w której dochodzi do sprzeczności z podstawowymi zasadami porządku prawnego. Wobec powyższego zatem to rozwiązanie jest nie do przyjęcia. Drugie rozwiązanie to tak zwane dostosowywanie polegające na tym, że sędzia może utworzyć nową normę kolizyjną, która byłaby syntezą przepisów obu systemów prawnych. Byłaby to przy tym norma będąca syntezą przepisów materialnych tych państw. Wątpliwość rodzi w tym miejscu fakt, że sędzia nie ma kompetencji prawotwórczych. W końcu sędzia może spośród dwóch praw wskazanych przez każdą z norm kolizyjnych wybrać jedno, najbardziej związane ze stosunkiem prawnym. Decyduje przy tym wola sędziego, a nie stron, przy czym nie musi się on kierować kryterium, które z praw zostałoby wybrane przez strony. Sędzia natomiast może dokonać swojego wyboru tylko spośród norm wskazanych przez normy kolizyjne z art. 31 (T. Pajor, op. cit., s. 684-688).

13 Ibidem, s. 168-172. 
interpretacyjny rodziła również sytuacja, w której obydwie strony były co prawda obywatelami tego samego państwa, ale państwo to było zróżnicowane pod względem obowiązujących w jego poszczególnych regionach systemów prawnych ${ }^{14}$.

Praktyczny problem w przypadku stosowania art. $31 \S 2$ mógł pojawić się także w sytuacji, w której jedna lub dwie strony stosunku zobowiązaniowego posiadały wiele obywatelstw. Na pierwszy rzut oka wydaje się, że zastosowanie $\mathrm{w}$ takiej sytuacji znajdował art. 2 prawa prywatnego międzynarodowego. W przypadku obywatela polskiego mającego jednocześnie więcej niż jedno obywatelstwo był to rzeczywiście art. $2 \S 1$, stosownie do którego jeżeli ustawa przewiduje właściwość prawa ojczystego, obywatel polski podlega prawu polskiemu, chociażby prawo innego państwa uznawało go za obywatela tego państwa. Natomiast w odniesieniu do cudzoziemca zastosowanie znajdował art. $2 \S 2$, stosownie do którego cudzoziemiec mający obywatelstwo dwóch lub więcej państw podlega, jako prawu ojczystemu, prawu tego z nich, z którym jest najściślej związany. Należy jednakże zwrócić uwagę na fakt, że przepis ten posługiwał się pojęciem ,,prawo ojczyste", które nie jest tożsame z obywatelstwem. Co więcej, w przypadku cudzoziemca istniała konieczność ustalania tego, z którym prawem jest najściślej związany, co wobec niedookreśloności pojęcia budziło znaczne problemy interpretacyjne. W związku z powyższym utrwaliło się stanowisko, że w przypadku, gdy albo po jednej, albo po dwóch stronach stosunku zobowiązaniowego występowało wielorakie obywatelstwo, należało najpierw sprawdzić, czy jedno z nich było obywatelstwem polskim i wtedy znajdował zastosowanie art. $31 \S 2$. W tym miejscu należy przy tym podkreślić, że wymóg najściślejszego związku z art. 2 $\S 2$ stanowił dodatkową przesłankę i zastępował tym samym domicyl z art. $31 \S 2$, podczas gdy artykuł ten samodzielnie regulował przesłanki zastosowania prawa w sytuacji w nim określonej, a zatem takie odniesienie było zbędne. Podobna sytuacja miała miejsce w przypadku, gdy obydwie strony stosunku zobowiązaniowego albo tylko jedna z nich nie miały obywatelstwa żadnego państwa. W tym miejscu pojawia się pytanie, czy należy zastosować art. 3 prawa prywatnego międzynarodowego, stosownie do którego jeżeli ustawa przewiduje właściwość prawa ojczystego, a obywatelstwa danej osoby ustalić nie można albo osoba ta nie ma obywatelstwa żadnego państwa, stosuje się prawo państwa, w którym znajduje się jej miejsce zamieszkania. Przepis ten ponownie odnosił się bowiem do pojęcia prawa ojczystego, którym nie posługiwał się art. $31 \S 2$. W tym przypadku przeważało rozwiązanie, że w odniesieniu do bezpaństwowców łącznik miejsca zamieszkania jest jedyny i wystarczający do zastosowania tego przepisu ${ }^{15}$.

Kolejną kwestią interpretacyjną, która miała miejsce na gruncie art. $31 \S 2$, było to, czy znajdował on zastosowanie w przypadku, gdy stronami stosunku prawnego były osoby prawne, a nie fizyczne. Ostatecznie przeważał pogląd przemawiający za

${ }^{14}$ Ibidem, s. 174-176.

15 B. Tracz-Pasternak, op. cit., s. 90-92. 
rozszerzającą interpretacją tego przepisu ${ }^{16}$. Pomimo iż posługiwał się on pojęciami immanentnie związanymi z osobami fizycznymi, takimi jak obywatelstwo czy miejsce zamieszkania, to nie należy zapominać, że odnosił się do stron stosunku prawnego. Tymczasem pod pojęciem strony rozumie się zarówno osoby fizyczne, jak i prawne. Nie ma przy tym potrzeby, aby na użytek prawa prywatnego międzynarodowego nadawać temu pojęciu inny charakter, interpretując je w sposób zawężony ${ }^{17}$. Co więcej, za zawężoną interpretacją art. $31 \S 2$ nie przemawia pogląd, że osoba prawna jako twór różny od osoby fizycznej nie może posiadać ani obywatelstwa, ani miejsca zamieszkania, obydwie te funkcje w przypadku osób prawnych pełni bowiem siedziba.

Przyjmuje się, że na gruncie ustawy z 1965 roku prawo prywatne międzynarodowe skumulowany łącznik obywatelstwa i miejsca zamieszkania był równoznaczny z łącznikiem siedziby ${ }^{18}$.

\section{Podsumowanie}

Uzasadnienia dla przyznania pierwszeństwa prawu miejsca czynu poszukuje się w normalnej ocenie zachowania sprawcy, którego należy oceniać według zasad panujących w miejscu popełnienia czynu. Takie podejście jest bardzo przydatne, gdy chodzi o uzasadnienie obciążenia sprawcy odszkodowaniem obowiązującym w miejscu popełnienia czynu, gdyż w wielu ustawodawstwach wysokość odszkodowania jest wprost proporcjonalna do stopnia winy ${ }^{19}$. Kolejną zaletę tego łącznika, wskazywaną w literaturze przedmiotu, stanowi fakt, że wskazane przez niego prawo jest często zbieżne z prawem miejsca sądu, zapewnia także jednolitość rozstrzygnięć ${ }^{20}$.

Jednocześnie jednak nie ulega wątpliwości, że łącznik ten faworyzuje sprawcę czynu niedozwolonego chociażby z tego względu, że umożliwia mu przewidzenie zasad, według których będzie on ponosił odpowiedzialność. Sprawca szkody musi zachowywać się zgodnie z normami obowiązującymi tylko w miejscu działania, podczas gdy w zasadzie powinien przestrzegać także te normy prawne,

16 Kwestię rozciągnięcia zakresu art. $31 \S 2$ także na osobę prawną rozwiązały ostatecznie dwa orzeczenia Sądu Najwyższego - wyrok SN z dnia 22 listopada 1972 roku, „Orzecznictwo Sądów Polskich i Komisji Arbitrażowych" 1974, nr 1, poz. 6; oraz uchwała SN z dnia 5 października 1974 roku, „Orzecznictwo Sądów Polskich i Komisji Arbitrażowych” 1976, nr 11, poz. 202, które dopuściły jego stosowanie także w stosunku do tych podmiotów.

17 B. Tracz-Pasternak, op. cit., s. 89. Tak też podnosił Sąd Najwyższy w wyroku z 22 listopada 1972 roku, „Orzecznictwo Sądów Polskich i Komisji Arbitrażowych” 1974, nr 1, poz. 6.

18 W. Klyta, Teoria powstania osoby prawnej w prawie prywatnym międzynarodowym, „Problemy Prawa i Handlu Zagranicznego" 19-20, 2000, s. 167 n.

19 M. Hancock, Torts in the Conflict of Laws, Chicago 1942, s. 54-62.

${ }^{20} \mathrm{~K}$. Przybyłowski, Nowe polskie unormowanie problematyki kolizyjnej prawa prywatnego międzynarodowego, „Studia Cywilistyczne” 8, 1966, s. 30. 
które obowiązują w miejscu, gdzie ujawniły się skutki działania sprawcy ${ }^{21}$. Kolejnym argumentem przemawiającym za stosowaniem jest utrzymanie integralności systemu prawnego państwa poprzez zastosowanie własnych norm prawnych w sytuacji, gdy obowiązujące w nim prawo zostało naruszone przez delikt ${ }^{22}$. Następnie należy zwrócić uwagę na fakt, że posługiwanie się tym łącznikiem prowadzi do ustalenia pewnych standardów postępowania, a co za tym idzie - do ujednolicenia rozstrzygnięć. Ponadto łącznik ten jest łatwy w stosowaniu ${ }^{23}$.

Niewątpliwą zaletą tego łącznika jest jego konkretność i jednoznaczność, ale jednocześnie zauważyć należy, że ma to miejsce tylko wtedy, kiedy ustawodawca z góry poczynił założenie, czy mamy do czynienia z łącznikiem prawa miejsca wystąpienia czynu niedozwolonego, czy też szkody.

Kontynuując krytykę łącznika lex loci delicti commissi, należy sięgnąć do argumentów M. Sośniaka, który w pierwszej kolejności ma zastrzeżenia do ,jednoznaczności" pojęcia czynu. Nie chodzi tu przy tym o różnice doktrynalne, ale o samo fizyczne działanie sprawcy, które może składać się z wielu elementów, z których każdy może być oceniany jako oddzielny czyn. Sytuacja taka występuje na przykład w przypadku wysłania listu z pogróżkami, gdzie miejscem popełnienia czynu, w zależności od przyjętej koncepcji, może być zarówno miejsce napisania listu, wrzucenia go do skrzynki czy też w końcu dotarcia do rąk adresata. Podobnie w przypadku tak zwanych deliktów prasowych czy też telewizyjnych. Po trzecie, koncepcja ta zawodzi całkowicie w sytuacji, gdy jeden czyn jest następstwem drugiego, przy czym dopiero oba łącznie traktowane są jako delikt. Przykładem takim jest m.in. sytuacja, gdy sprawca najpierw obezwładnia ofiarę, a potem ją zabija. Mieczysław Sośniak negatywnie ocenia przy tym koncepcję, według której należy brać pod uwagę tylko czyn ostatni — ten, który określa skutek, stanowi to bowiem w istocie przekreślenie idei całej zasady. Z kolei niemożliwa jest łączna ocena wszystkich czynów, gdyż byłoby to rozwiązanie zbyt skomplikowane. Ponadto duży problem powstaje w przypadku odpowiedzialności za osoby trzecie. Kontrowersyjnym zagadnieniem jest bowiem możliwość kwalifikacji jako

${ }^{21}$ M. Sonnentag, Zur Europäisierung des Internationalen ausservertraglichen Schuldrechts durch die geplante Rom II-Verordnung, „Zeitschrift für Vergleichende Rechtswissenschaft” 2006, nr 105, s. 267.

22 C.G.J. Morse, Torts in Private International Law, Amsterdam-New York-Oxford 1978, s. 113-114; por. też E. Rabel, The Conflict of Laws. A Comparative Study, t. 2, Chicago 1945, s. 303306, 311-323. Nie wydaje się jednak, aby na obecnym etapie rozwoju prawa prywatnego międzynarodowego, a zwłaszcza europejskiego prawa prywatnego międzynarodowego, które dąży do wskazania prawa jak najściślej związanego z danym stanem faktycznym, kwestia zachowania integralności państwowego systemu prawnego była aż tak istotna.

${ }^{23}$ M. Sośniak, Zobowiązania nie wynikające..., s. 24. Należy mieć jednak na uwadze, że jednolitość rozstrzygnięć będzie możliwa tylko wtedy, kiedy ustawodawca wyraźnie opowie się, czy prawem właściwym jest prawo miejsca wystąpienia zdarzenia powodującego czyn niedozwolony, czy też szkody. W przeciwnym bowiem razie to właśnie orzecznictwo będzie za każdym razem opowiadało się za jedną z tych opcji, biorąc pod uwagę okoliczności danego przypadku. Taki stan rzeczy nie będzie na pewno sprzyjał ani przejrzystości rozstrzygnięć, ani łatwości stosowania tej zasady. 
czynu niedopełnienia tak zwanego obowiązku pieczy. W końcu koncepcja ta jest także sztuczna w przypadku deliktów z zaniechania. Jej zwolennicy jako miejsce popełnienia deliktu przyjmują bowiem to, gdzie znajdował się sprawca w chwili, w której dopuścił się zaniechania, bądź też właściwość miejsca, gdzie istniał obowiązek działania. W pierwszym przypadku problem powstaje, gdy takiego miejsca nie da się oznaczyć albo przy braku dokładnego terminu popełnienia czynu (gdy na przykład dana osoba przebywała wówczas w kilku miejscach). Z kolei w przypadku drugiego rozwiązania problem powstaje, gdy nie da się określić miejsca, w którym istniał obowiązek działania ${ }^{24}$.

Następnie należy się również zgodzić z ogólnie przyjętym poglądem, że omawiany łącznik jest zupełnie nieprzydatny w przypadku tak zwanej odpowiedzialności opartej na zasadzie ryzyka, nie jest ona bowiem warunkowana koniecznością dokładnego zidentyfikowania czynu sprawczego ${ }^{25}$.

Stosowanie łączników personalnych było poddane krytyce przede wszystkim w dawniejszej doktrynie prawa prywatnego międzynarodowego. W pierwszej kolejności wysuwany był argument, że położenie głównego nacisku na takie kryteria, jak obywatelstwo czy domicyl stron, powoduje, że pomimo iż do wyrządzenia szkody doszło w jednym miejscu, będzie ono odmiennie oceniane w zależności od statutu personalnego stron ${ }^{26}$. Za czyn popełniony w tym samym miejscu odpowiedzialność powinna być zawsze poniesiona na tej samej podstawie prawnej. Wady koncepcji stosowania statutu personalnego uwidaczniają się najpełniej w sytuacji, gdy w konflikt zamieszana jest osoba trzecia, inna niż sprawca szkody i poszkodowany. Niektórzy przedstawiciele doktryny twierdzą wprost, że stosowanie łączników personalnych prowadzi do naruszenia zasady równości stron wobec prawa. Następnie wskazują na fakt, że ani obywatelstwo, ani domicyl nie należą do elementów przedmiotowo istotnych $\mathrm{w}$ przypadku popełnienia czynu niedozwolonego. Stosunek deliktowy nawiązuje się pomiędzy jego stronami dopiero w momencie popełnienia czynu niedozwolonego i nie mają na to wpływu ani obywatelstwo, ani domicyl którejś z nich. Aby więc łączniki personalne mogły mieć zastosowanie, pomiędzy stronami powinno jeszcze istnieć powiązanie innego rodzaju, powstałe przed powstaniem stosunku deliktowego ${ }^{27}$.

Obecnie poszukuje się uzasadnienia dla stosowania wspólnego prawa personalnego ${ }^{28}$ stron, które jest najściślej związane $\mathrm{z}$ daną sprawą. W mojej ocenie

24 M. Sośniak, Lex loci..., s. 148-154.

25 Ibidem.

26 T. Pajor, op. cit., s. 97-98.

27 Ibidem.

28 Niektórzy autorzy podnoszą jednak, że istnieje również taka grupa sytuacji, gdzie uzasadnione będzie stosowanie prawa personalnego tylko jednej strony — na przykład wtedy, gdy wystąpi zupełny brak związku pomiędzy osobą odpowiedzialną a miejscem działania, w sytuacji, gdy delikt zostanie popełniony przez osobę pozostającą pod pieczą czy też pod nadzorem. Podobnie przyjmuje się w wypadku wad konstrukcji obciążających konstruktora. W niektórych przypadkach powinno być zatem dopuszczalne stosowanie prawa personalnego tylko jednej ze stron stosunku zobowiązaniowego. Powinno to mieć miejsce zwłaszcza w sytuacji, gdy z okoliczności danego przypadku 
za zastosowaniem łączników personalnych wydają się przemawiać również inne argumenty, które są powszechnie wyrażane w literaturze przedmiotu. W pierwszej kolejności podkreślić należy, że rozstrzygnięcie wydane na podstawie prawa miejsca zamieszkania lub pobytu stron jest dla nich najbardziej przewidywalne i zrozumiałe. Łącznik ten zapewnia ponadto związek z miejscem, w którym skoncentrowane są sprawy życiowe (ośrodek życiowy) stron, podczas gdy miejsce wystąpienia czynu niedozwolonego lub szkody jest najczęściej zupełnie przypadkowe. Co więcej, strony po wystąpieniu czynu niedozwolonego prawie zawsze wracają do miejsca swojego zwykłego pobytu lub zamieszkania. Za zastosowaniem tego łącznika przemawia też niewątpliwie ekonomia procesowa. Przeprowadzenie postępowania w miejscu wspólnego pobytu stron jest bowiem niewątpliwie najtańszym rozwiązaniem, niewymagającym na przykład specjalistycznych usług prawnych czy też udziału tłumaczy. Niewątpliwą zaletą tego łącznika jest też to, że w przypadku, gdy strony znajdują się w izolowanym środowisku (na przykład spędzają urlop razem, mają wspólne miejsce zatrudnienia itp.), zastosowanie prawa wspólnego miejsca pobytu doprowadzi do bardziej sprawiedliwego rezultatu, jako że będzie ściślej związane ze stronami i miejscem, w którym szkoda zostanie poniesiona ${ }^{29}$. Im krótszy i bardziej przejściowy okres pobytu stron za granicą, tym bardziej odpowiednie i sprawiedliwe wydaje się zastosowanie prawa miejsca ich wspólnego pobytu, zarówno jeśli chodzi o standardy zabezpieczenia, jak i wspólnego środowiska życiowego ${ }^{30}$.

Jednocześnie jednak nie należy lekceważyć przytoczonych na wstępie tego rozdziału argumentów doktryny. Oparcie się bowiem tylko i wyłącznie na łącznikach personalnych doprowadziłoby do tego, że całkowicie na znaczeniu straciłby związek danego czynu niedozwolonego z państwem, w którym doszło do zdarzenia powodującego szkodę, bądź też do wystąpienia samej szkody. Konsekwentnie stosowanie tylko i wyłącznie tego łącznika doprowadziłoby zatem do tego, że niepotrzebne byłyby wszystkie inne łączniki i to nie tylko w zakresie prawa właściwego dla deliktów.

$\mathrm{Z}$ tych względów łącznik personalny powinien mieć przede wszystkim charakter pomocniczy, to znaczy - powinien korygować negatywne skutki zastosowania lex loci delicti commissi, takie jak przypadkowość miejsca wystąpienia zdarzenia powodującego szkodę lub samej szkody. Wydaje się jednak, że nie wzięli tego pod uwagę twórcy rozporządzenia Rzym II, którzy łącznik ten skonstruowali na zasadzie wszystko albo nic.

wynika, że nie powinno być dopuszczalne tak zwane powiązanie terytorialne (M. Sośniak, Zobowiązania..., s. 59).

29 Ibidem.

30 T.K. von Graziano, Das auf ausservertragliche Schuldverhaeltnisse anzuwendende Recht nach Inkrafttreten der Rom II-Verordnung, ,Rabels Zeitschrift fuer auslaendisches und internationales Privatrecht" 73, 2009, nr 1, s. 18. 


\section{Bibliografia}

\section{Wykaz źródeł}

Ustawa z dnia 2 sierpnia 1926 roku o prawie właściwym dla stosunków prywatnych międzynarodowych (Dz.U. z 1926 r. Nr 101, poz. 581 ze zm.).

Ustawa z dnia 12 listopada 1965 roku - Prawo prywatne międzynarodowe (Dz.U. z 1965 r. Nr 46, poz. 290).

\section{Wykaz literatury}

Arminjon P., Précis de droit international privé, t. 2, Paryż 1934.

Graziano T.K. von, Das auf ausservertragliche Schuldverhaeltnisse anzuwendende Recht nach Inkrafttreten der Rom II-Verordnung, ,Rabels Zeitschrift fuer auslaendisches und internationales Privatrecht" 73, 2009, nr 1.

Hancock M., Torts in the Conflict of Laws, Chicago 1942.

Klyta W., Teoria powstania osoby prawnej w prawie prywatnym międzynarodowym, „Problemy Prawne Handlu Zagranicznego" 19-20, 2000.

Mączyński A., Zamieszkanie jako podstawa łącznika normy kolizyjnej, „Zeszyty Naukowe UJ” 1978, $\mathrm{nr} 81$.

Morse C.G.J., Torts in Private International Law, Amsterdam-New York-Oxford 1978.

Niboyet J.P., Traité de droit international privé français, t. 5, Paryż 1948.

Pajor T., Odpowiedzialność deliktowa w prawie prywatnym międzynarodowym, Warszawa 1989.

Pillet A., Traité pratique de droit international privé, t. 2, Paryż 1923.

Przybyłowski K., Nowe polskie unormowanie problematyki kolizyjnej prawa prywatnego międzynarodowego, „Studia Cywilistyczne” 8, 1966.

Rabel E., The Conflict of Laws. A Comparative Study, t. 2, Chicago 1945.

Sonnentag M., Zur Europäisierung des Internationalen ausservertraglichen Schuldrechts durch die geplante Rom II-Verordnung, „Zeitschrift für Vergleichende Rechtswissenschaft” 2006, nr 105.

Sośniak M., Lex loci delicti comissi w prawie międzynarodowym prywatnym, „Studia Cywilistyczne" $1963, \mathrm{nr} 4$.

Sośniak M., Zobowiązania nie wynikające z czynności prawnych w prawie prywatnym międzynarodowym, Katowice 1971.

Tracz-Pasternak B., Właściwość prawa personalnego stron dla zobowiazań niewynikajacych z czynności prawnych, „Państwo i Prawo” 1980, nr 2.

\section{Orzeczenia sądowe}

Uchwała SN z dnia 5 października 1974 roku, „Orzecznictwo Sądów Polskich i Komisji Arbitrażowych" 1976, nr 11, poz. 202.

Wyrok SN z dnia 22 listopada 1972 roku, „Orzecznictwo Sądów Polskich i Komisji Arbitrażowych” 1974, nr 1, poz. 6. 